Thorax (1976), 31, 94.

\title{
Hypoxia and lung mast cells: influence of disodium cromoglycate
}

\author{
I. P. F. MUNGALL \\ Academic Division of Medicine, University of Sheffield, New Medical School, Beech Hill Road, Sheffield \\ SI0 $2 R X$
}

\begin{abstract}
Mungall, I. P. F. (1976). Thorax, 31, 94-100. Hypoxia and lung mast cells: influence of disodium cromoglycate. Rats kept in $10 \% \mathrm{O}_{2}$ for three or more weeks developed mast cell hyperplasia in the lungs, especially around the alveoli and the small peripheral blood vessels, which become thickened during chronic hypoxia. There was a significant correlation between the degree of right ventricular hypertrophy $(\mathrm{RVH})$ and the numbers of alveolar and small vessel mast cells. However, mast cell hyperplasia developed more slowly than RVH. Daily treatment with disodium cromoglycate failed to prevent RVH in hypoxic conditions but was associated with retardation of growth in both hypoxic and control rats. Neither acute nor chronic hypoxia increased the degree of degranulation in the lung mast cells.
\end{abstract}

Changes in alveolar oxygen tension control pulmonary vascular tone (von Euler and Liljestrand, 1946; Barer et al., 1969; Abraham et al., 1970). The pulmonary pressor response to hypoxia is not dependent on extrinsic nerves and could be due to a chemical transmitter. Increased levels of histamine have been found in the pulmonary venous blood from hypoxic lungs (Aviado, Samanek, and Folle, 1966; Haas and Bergofsky, 1972) though Brashear, Martin, and Ross (1970) and Dawson et al. (1974) were unable to confirm this. The pulmonary pressor response to hypoxia in the rat is inhibited by antihistamines and enhanced by histaminase inhibitors (Hauge, 1968). The mast cell degranulating agent, $48 / 80$, abolishes the hypoxic vascular response in the cat (Barer and McCurrie, 1969; Hauge and Staub, 1969; Dawson et al., 1974) though there is disagreement as to its exact mechanism of action. Lung mast cell granules are a potent source of histamine (Riley and West, 1953; Fawcett, 1954; Riley and West, 1955; Bray and van Arsdel, 1961). Haas and Bergofsky (1972) have shown that suspensions of rat peritoneal mast cells discharge histamine when hypoxic gases are bubbled through them. In view of the relationship between mast cells, histamine, and pulmonary vasoconstriction, it is possible that mast cells may play a functional role in the pulmonary arteriolar and right ventricular hypertrophy (RVH) which develop during chronic hypoxia (Naeye and Bickerman, 1959; Hicken et al., 1965; Hasleton, Heath, and Brewer, 1968; Heath, Brewer, and Hicken, 1968; Abraham et al., 1971; Hunter et al., 1974). Changes in the population and distribution of mast cells have therefore been sought in chronically hypoxic rato lungs.

If the RVH of chronic hypoxia resulted from $\cong$ pulmonary hypertension caused by sustained hista- $\overrightarrow{\overrightarrow{0}}$ mine release from the mast cells, then the mast cell 3 stabilizing drug, disodium cromoglycate, might prevent this chain of events. Initially disodium cromoglycate was thought to be effective only in IgEF mediated antigen/antibody reactions (Altounyan, $\frac{\mathrm{O}}{\mathrm{N}}$ 1967; Cox, 1967; Assem and Richter, 1971) but it has $x$ now been observed to inhibit mast cell degranulation in many situations quite unrelated to reaginic antibody (IgE) reactions (Pepys et al., 1968; Davies, 1968; Orr and Cox, 1969; Altounyan, Cox, and Orr, 1970; Kerr, Govindaraj, and Patel, 1970; de Kock, 1970;은 Clarke, 1971; Marshall, 1972). It probably acts by stabilizing the mast cell membrane regardless of the stimulus, and it is therefore possible that disodium $N$ cromoglycate might prevent hypoxic mast celf degranulation. This hypothesis has been tested by determining whether pretreatment with disodium $\omega$ cromoglycate prevented RVH in chronically hypoxic? rats.

In a further series of experiments the degree of mast cell degranulation during hypoxia has been assessed.? Haas and Bergofsky (1972) showed increased mast $\frac{0}{\circ}$ cell degranulation in acutely hypoxic rat lungs, $\frac{}{\mathbb{C}}$ though Kay, Waymire, and Grover (1974), using a? histochemical assay, were unable to detect any evi- $\varrho$ dence of histamine depletion from the mast cello during acute hypoxia. In the experiments describedo 
here, mast cell degranulation has been measured in both acutely and chronically hypoxic rat lungs. Different anaesthetics and methods of fixation have been used to determine whether these have any influence on mast cell degranulation. Preliminary accounts of part of this work have already been published (Barer and Mungall, 1974; Mungall and Barer, 1975).

\section{MATERIAL AND METHODS}

Male albino Wistar rats were used in all experiments.

POPULATION AND DISTRIBUTION OF MAST CELLS IN CHRONIC HYPOXIA The 21-day-old rats were allowed to accommodate to the laboratory for 4-7 days. Littermates were then divided so that half were kept in a low $\mathrm{O}_{2}$ chamber for varying periods and half were kept in the same room in ambient air. Two chambers (1 and 2) maintained at $10 \% \mathrm{O}_{2}$ were used. In chamber 1 (internal dimenisions $86 \times 86 \times 44 \mathrm{~cm}$; Cryer and Bartley, 1974) $\mathrm{CO}_{2}$ was absorbed by circulating the contained gases through concentrated $\mathrm{KOH}$; this was changed when its $\mathrm{pH}$, measured daily, began to fall. $\mathrm{PCO}_{2}$ was not measured in these experiments. Owing to doubt as to the efficiency of $\mathrm{CO}_{2}$ absorption, the experiments were repeated (with similar results) in a second improved chamber $(65 \times 65 \times 150 \mathrm{~cm})$ where $\mathrm{PCO}_{2}$ was measured and did not rise above $0.6 \%$. Temperature and humidity were always slightly higher inside than outside the chambers. Rats were given free access to food (Oxoid diet 86) and water. The chamber was opened for about one hour two or three times weekly for cleaning and restocking.

At the end of each experiment the rats from the chamber and their littermate controls were killed with ethyl chloride and $60 \mathrm{mg}$ pentobarbitone intraperitoneally. The lungs were fixed with buffered formol saline either by intratracheal injection of $9 \mathrm{ml}$ or infusion at $1.96 \mathrm{kPa}$ pressure. Transverse sections at $7 \mu \mathrm{m}$ were made and stained with azure eosin. One complete section, or two sections from different lobes in the early experiments using chamber 1 , were scanned by one observer, who was unaware of each section's source. A total mast cell count was made and a note of the position of each mast cell, whether in the bronchi, the pleura, adjacent to large pulmonary vessels (those greater than $125 \mu \mathrm{m}$ diameter), small pulmonary vessels (less than $125 \mu \mathrm{m}$ ), or in the alveolar septa or ducts. In view of the difficulty of recognition, no attempt was made to differentiate small arteries and arterioles from small veins. In addition, four sections were scanned by a second independent observer to check the degree of observer variation. All counts were expressed in terms of unit area of lung section, measured by planimetry after projection onto graph paper.
The size of the RVs in one experiment was assessed by dissecting the free wall of the RV from the septum and left ventricle (LV). The ventricles were blotted and weighed.

DISODIUM CROMOGLYCATE EXPERIMENTS It was necessary to find a daily period of hypoxia which would cause changes in the heart but not exceed the duration of action of disodium cromoglycate which is estimated to be four hours after intraperitoneal injection. The regime used by Widimsky et al. (1972) and McGrath et al. (1973) was repeated. Rats were exposed to $8 \% \mathrm{O}_{2}$ for four hours daily. After 20 and 24 exposures there was no change in RV size but after 70 exposures the mean RV weight for five hypoxic rats was $0.213 \mathrm{~g}(\mathrm{SD} \pm 0.057)$ and for six control rats $0.139 \mathrm{~g}(\mathrm{SD} \pm 0.039), \mathrm{P}=0.01-0.025$.

For the main experiment, 89-day-old rats were divided into the following groups, each of six rats: (A) hypoxic, injected with disodium cromoglycate; (B) hypoxic, injected with saline; (C) control, injected with disodium cromoglycate; and (D) control, injected with saline. Six animals died in the course of the experiment, one from group $A$, two from $B$, and three from D. Each morning the rats were weighed, sedated with ether, and injected intraperitoneally with $10 \mathrm{mg} / \mathrm{kg}$ disodium cromoglycate (Intal, Fisons Pharmaceuticals, $1 \mathrm{mg}$ per $\mathrm{ml}$ in saline) or an equivalent volume of $0.9 \%$ saline. Groups A and B were then placed in the chamber at $8 \% \mathrm{O}_{2}$ for four hours. The maximum interval between injection and exposure was 20 minutes. This regime was carried out for six days a week for 70 exposures. In between exposures the animals were subject to normal atmospheric conditions. After 70 exposures the rats were killed with ethyl chloride and $60 \mathrm{mg}$ pentobarbitone intraperitoneally. The heart and lungs were removed, the ventricles weighed, and the lungs fixed and sectioned, as described above. Blood from the inferior vena cava was taken for haematocrit estimations. One section from each lung was scanned 'blind' and the numbers of mast cells were counted.

DEGRANULATION EXPERIMENTS Rats were anaesthetized with ethyl chloride and $7 \mathrm{mg}$ pentobarbitone intraperitoneally. A small polyethylene cannula was inserted into the trachea. The animals were ventilated with $10 \% \mathrm{O}_{2}$ in $\mathrm{N}_{2}$ through a $\mathrm{T}$ piece connected to the tracheal cannula for either $5,10,15$ or 30 minutes. Two control rats were ventilated with $100 \% \mathrm{O}_{2}$. The experiment was terminated by injecting $9 \mathrm{ml}$ formol saline into the tracheal cannula. This has the advantage that the lungs are fixed immediately at the time of death, thus preventing postmortem disruption of the mast cells. The lungs were removed and transverse 
sections were prepared as above. One complete section from each lung was scanned 'blind' by a single observer. The degree of mast cell degranulation was noted, using the classification of Haas and Bergofsky (1972): grade $1=$ intact, $2=$ partial degranulation, $3=$ complete degranulation. An overall degranulation index, from 1 to 3 , was also calculated from this formula: degranulation index $=(x+2 y+3 z) / n$, where $x=$ the number of grade 1 mast cells, $y=$ the number of grade $2, z=$ the number of grade 3 , and $\mathrm{n}=$ the total number in any section. Thus, the degranulation index for an animal whose mast cells were predominantly intact would tend towards 1 , while for an animal with predominantly maximally degranulated mast cells the index would tend towards 3.

In a second experiment, rats were placed individually in a small perspex chamber $(18 \times 22 \times 9 \mathrm{~cm})$. They were divided into three groups exposed to either $10 \% \mathrm{O}_{2}, 12 \% \mathrm{O}_{2}$ or, in the case of the controls, air. For the experimental animals, air was sucked through the chamber initially, and after 30 minutes the gas mixture was changed to either $10 \% \mathrm{O}_{2}$ or $12 \% \mathrm{O}_{2}$ in $\mathrm{N}_{2}$. After 30, 40, 60 or 90 minutes the experiment was terminated by injecting $30 \mathrm{ml}$ ether through a rubber bung into the chamber. The rat was removed and killed with an intraperitoneal injection of $60 \mathrm{mg}$ pentobarbitone, and the lungs were dissected out, fixed, and sectioned. The whole procedure from removal of the rat to completion of the dissection and fixation took between five and eight minutes (mean six minutes).

The degree of degranulation in a group of rats kept in the large hypoxic chamber (chamber 1) at $10 \% \mathrm{O}_{2}$ for 56 days was also assessed. The rats were killed shortly after removal from the chamber with ethyl chloride and $60 \mathrm{mg}$ pentobarbitone intraperitoneally. The sections were prepared and scanned as described above. Littermates who had been exposed to atmospheric conditions acted as controls.

T A B L E I

EFFECT OF CHRONIC HYPOXIA ON LUNG MAST CELLS

\begin{tabular}{|c|c|c|c|c|c|c|c|}
\hline \multirow[b]{2}{*}{ No. of Rats } & \multirow{3}{*}{$\begin{array}{c}\begin{array}{c}\text { Days of } \\
\text { Exposure to } \\
10 \% \mathrm{O}_{2}\end{array} \\
80 \\
70 \\
56 \\
21\end{array}$} & \multicolumn{3}{|c|}{ Total Mast Cell Count $/ \mathrm{cm}^{2}$} & \multicolumn{3}{|c|}{ Alveolar and Small Vessel Mast Cell Count $/ \mathrm{cm}^{2}$} \\
\hline & & Hypoxic & Control & $\mathbf{P}$ & Hypoxic & Control & $\mathbf{P}$ \\
\hline $\begin{array}{rr}\mathrm{a} & \mathbf{6}^{1} \\
\mathrm{~b} & 10^{1} \\
\mathrm{c} & 8^{1} \\
\mathrm{~d} & 9^{1}\end{array}$ & & $\begin{array}{l}447 \pm 130 \\
607 \pm 155 \\
443 \pm 267 \\
293 \pm 79\end{array}$ & $\begin{array}{l}181 \pm 65 \\
237 \pm 122 \\
389 \pm 108 \\
352 \pm 192\end{array}$ & $\begin{array}{c}<0.001 \\
0.001 \\
\text { NS } \\
\text { NS }\end{array}$ & $\begin{array}{r}143 \pm 75 \\
104 \pm 53 \\
105 \pm 89 \\
58 \pm 41\end{array}$ & $\begin{array}{l}43 \pm 35 \\
14 \pm 12 \\
26 \pm 18 \\
55 \pm 66\end{array}$ & $\begin{aligned}< & 0.01 \\
< & 0.001 \\
< & 0.05 \\
& \text { NS }\end{aligned}$ \\
\hline $\begin{array}{cr}\mathrm{e} & 12^{2} \\
\mathrm{f} & 10^{2} \\
\mathrm{~g} & 6^{2}\end{array}$ & $32 \underset{14}{21}$ or 34 & $\begin{array}{l}743 \pm 109 \\
896 \pm 431 \\
300 \pm 53\end{array}$ & $\begin{array}{l}478 \pm 116 \\
381 \pm 279 \\
299 \pm 177\end{array}$ & $\begin{array}{r}<0.01 \\
\text { NS } \\
\text { NS }\end{array}$ & $\begin{array}{l}179 \pm 78 \\
150 \pm 111 \\
13 \pm 7\end{array}$ & $\begin{array}{c}32 \pm 28 \\
29 \pm 13 \\
2 \pm 2\end{array}$ & $\begin{array}{r}<0.01 \\
<0.05 \\
\text { NS }\end{array}$ \\
\hline
\end{tabular}

"Chamber 1: Two sections counted from each animal.

${ }^{2}$ Chamber 2: One section counted from each animal.

To ensure that the method was sufficiently sensitive to detect mast cell degranulation, two rats were injected with the mast cell degranulating agent, $\frac{\bar{\sigma}}{2}$ $48 / 80 ; 1 \mathrm{mg} / \mathrm{kg}$ was injected intraperitoneally and the animals were killed either two or four hours later with ether and $60 \mathrm{mg}$ pentobarbitone intraperitoneally. कs

Means and standard deviations are given in the text. and tables and were compared by Student's $t$ test for unpaired data. Regressions were calculated by the method of least squares and their significance was $₹$ tested by the $t$ test.

\section{RESULTS}

POPULATION AND DISTRIBUTION OF MAST CELLS IN CHRONIC HYPOXIA In five experiments (duration 21-80 days) there was an increase in total mast cello count (Table I), and in three of these the increase reached statistical significance. This mast cell hyper-0 plasia was apparent in all situations in the lung but was prominent around small peripheral vessels and alveoli, indicated in the right-hand columns of Table I ( $P<0.05$ for all five experiments). In the 14-C day and one of the 21-day experiments ( $g$ and $d)$ there was no mast cell hyperplasia. There was good correlation between the counts by the two observerso $(r=0.991, P<0.001)$ and between counts obtained $\frac{\mathbb{Q}}{2}$ from different lobes of the same lung (experiment $b:=$ $r=0.809, P<0.001$ for the total count, and $r=0.579$, $P<0.01$ for the alveolar and small vessel count).

In experiment $e$, in which ventricles were weighed there was RVH in the hypoxic group; the mean hypoxic RV weight was $0.263 \pm 0.031 \mathrm{~g}$ and theo control weight $0.148 \pm 0.031 \mathrm{~g}(\mathrm{P}<0.005)$. There was significant correlation $(r=0.879, P<0.05)$ betweenothe hypoxic RV weight and the alveolar and smalle vessel mast cell count in each rat (Fig. 1).

DISODIUM CROMOGLYCATE EXPERIMENTS The RV? weights, expressed in absolute terms, in relation to 


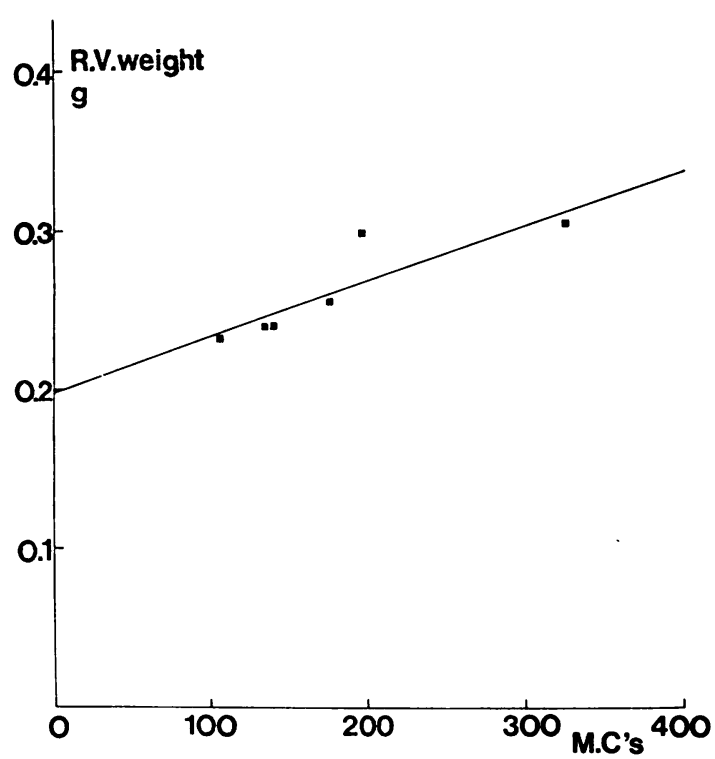

FIG. 1. Relationship between $R V$ weight and alveolar and small vessel mast cell count (M.C.) Experiment $e$, Table I. Six rats, 21 days' exposure to $10 \% \mathrm{O}_{2}$. Regression line $(r=0.879, \mathrm{P}<0.05)$ is plotted.

body weight and as a ratio of left ventricle+septal weights are shown in Table II. There was no significant difference between the absolute RV weights in the two hypoxic groups (A and B). As expected, there was a clear increase in the RV weight of the hypoxic saline animals (B) compared with their controls (D). However, there was also RVH in the hypoxic disodium cromoglycate group (A) compared with their controls $(C)$. The difference between $R V$ weights in $C$ and $D$ was probably due to differences in body weight, as it was not apparent when the RV weights were normalized for body weight.
The ratio of $\mathrm{RV}$ weight to $\mathrm{LV}+$ septal weight is probably the most sensitive indicator of RV hypertrophy. From these ratios it can be seen that there was RVH in both the hypoxic groups (A and B) and that disodium cromoglycate had no protective action on the right ventricle.

Haematocrits, changes in body weight, and mast cell counts are also listed in Table II. Haematocrits were higher in the hypoxic groups compared with the controls; the reason for the slight but significant depression of haematocrit in the hypoxic disodium cromoglycate group (A) compared with B is unclear. As expected, the hypoxic animals failed to gain weight as rapidly as the controls. However, disodium cromoglycate also appeared to have a depressant effect on growth, in both the hypoxic animals and the controls, and in the hypoxic disodium cromoglycate group (A) the animals actually lost weight. There was no significant difference in the mast cell counts between any of the four groups, with regard to either the total count or the alveolar and small vessel count.

DEGRANULATION EXPERIMENTS The degranulation grades and overall index for the three experiments are shown in Table III. On comparing both the individual degranulation grades and the overall indices, there was no significant difference either between the hypoxic animals and the controls or between the individual experiments. The degree of degranulation in experiment i for all animals was slightly lower than in the other two experiments but the difference did not reach statistical significance.

The degree of degranulation in the perivascular mast cells might be expected to be greater than in the lung as a whole. This question was investigated in experiment ii. The perivascular mast cell degranulation index was $1.40,1.36$, and 1.67 for $10 \% \mathrm{O}_{2}$,

T A B LE I I

EFFECT OF CHRONIC INTERMITTENT HYPOXIA AND/OR DISODIUM CROMOGLYCATE (DSCG) ON BODY WEIGHT, RV WEIGHT, HAEMATOCRIT, AND LUNG MAST CELL COUNT

\begin{tabular}{|c|c|c|c|c|c|c|}
\hline & $\begin{array}{l}\text { (A) Hypoxic } \\
\text { DSCG (5) }\end{array}$ & $\begin{array}{l}\text { (B) Hypoxic } \\
\text { Saline (4) }\end{array}$ & $\begin{array}{l}\text { (C) Control } \\
\text { DSCG (6) }\end{array}$ & $\begin{array}{l}\text { (D) Control } \\
\text { Saline (3) }\end{array}$ & $\mathbf{P}$ & \\
\hline $\begin{array}{l}\text { Initial body weight (g) } \\
\text { Final body weight (g) } \\
\text { Change in body weight } \% \\
\text { Haematocrit } \% \\
\text { Total mast cell count/cm } \\
\text { Alveolar and small vessel count/cm } \\
\text { Mean RV weight (g) } \\
\text { RV/body weight (mg/g) } \\
\text { RV/LV + septum }\end{array}$ & $\begin{aligned} 359 \cdot 5 & \pm 31 \cdot 7 \\
347.0 & \pm 40.5 \\
-4.0 & \pm 4 \cdot 7 \\
67 & \pm 2 \\
369 & \pm 180 \\
27 & \pm 26 \\
0.211 & \pm 0.026 \\
0.608 & \pm 0.049 \\
0.30 & \pm 0.02\end{aligned}$ & $\begin{array}{c}368 \cdot 5 \pm 39 \cdot 3 \\
394.5 \pm 48.8 \\
+7 \cdot 0 \pm 6.0 \\
70 \pm 2 \\
224 \pm 84 \\
33 \pm 20 \\
0.204 \pm 0.022 \\
0.520 \pm 0.070 \\
0.30 \pm 0.02\end{array}$ & $\begin{array}{c}338.7 \pm 15.7 \\
351.0 \pm 21.5 \\
+3.6 \pm 3.6 \\
46 \pm 3 \\
444 \pm 184 \\
26 \pm 20 \\
0.142 \pm 0.013 \\
0.398 \pm 0.039 \\
0.21 \pm 0.03\end{array}$ & $\begin{aligned} 397 \cdot 0 & \pm 1 \cdot 7 \\
485 \cdot 7 & \pm 23 \cdot 6 \\
+22 \cdot 3 & \pm 5 \cdot 5 \\
43 & \pm 4 \\
334 & \pm 236 \\
46 & \pm 55 \\
0.171 & \pm 0.010 \\
0.350 & \pm 0.036 \\
0.22 & \pm 0.02\end{aligned}$ & $\begin{array}{l}\mathbf{A} / \mathbf{B}=<0.01 \\
\mathbf{B} / \mathbf{D}=<0.01 \\
\mathbf{A} / \mathbf{B}=<0.05 \\
\mathbf{B} / \mathbf{D}=<0.005 \\
\mathbf{N S} \\
\mathbf{N S} \\
\mathbf{A} / \mathbf{B}=\mathbf{N S} .05 \\
\mathbf{B} / \mathbf{D}=<0.05 \\
\mathbf{A} / \mathbf{B}=<0.025 \\
\mathbf{B} / \mathbf{D}=<0.01 \\
\mathbf{A} / \mathbf{B}=\mathbf{N S} \\
\mathbf{B} / \mathbf{D}=<0.005\end{array}$ & $\begin{array}{l}\mathbf{A} / \mathbf{C}=<0.01 \\
\mathbf{C} / \mathbf{D}=<0.005 \\
\mathbf{A} / \mathbf{C}=<0.005 \\
\mathbf{C} / \mathbf{D}=\mathbf{N S} \\
\mathbf{A} / \mathbf{C}=<0.005 \\
\mathbf{C} / \mathbf{D}=<0.01 \\
\mathbf{A} / \mathbf{C}=<0.005 \\
\mathbf{C} / \mathbf{D}=\mathbf{N S} \\
\mathbf{A} / \mathbf{C}=<0.005 \\
\mathbf{C} / \mathbf{D}=\mathbf{N S}\end{array}$ \\
\hline
\end{tabular}

*Number of rats in each group. 
T A B L E I I I

EFFECT OF ACUTE AND CHRONIC HYPOXIA ON LUNG MAST CELL DEGRANULATION

\begin{tabular}{|c|c|c|c|c|c|}
\hline \multirow[b]{2}{*}{ Experiment } & \multirow[b]{2}{*}{ No. of Rats } & & \multicolumn{2}{|c|}{ Hypoxic } & \multirow{2}{*}{$\frac{\text { Controls }}{\text { Air }}$} \\
\hline & & & $10 \% \mathrm{O}_{2}$ & $12 \% \mathrm{O}_{2}$ & \\
\hline i Acute hypoxia-anaesthetized & 7 & $\begin{array}{c}\text { Grade } 1 \% \\
\text { Grade } 2 \% \\
\text { Grade } 3 \% \\
\text { Overall index }\end{array}$ & $\begin{array}{c}63.7 \pm 10.4 \\
31.8 \pm 9.9 \\
4.5 \pm 3.1 \\
1.41 \pm 0.12\end{array}$ & & $\begin{array}{c}65.4 \pm 14.3 \\
29.2 \pm 11.7 \\
5.5 \pm 2.7 \\
1.40 \pm 0.17\end{array}$ \\
\hline ii Acute hypoxia-unanaesthetized & 9 & $\begin{array}{c}\text { Grade } 1 \% \\
\text { Grade } 2 \% \\
\text { Grade } 3 \% \\
\text { Overall index }\end{array}$ & $\begin{array}{c}47.9 \pm 23.6 \\
43.5 \pm 17.3 \\
8.6 \pm 6.5 \\
1.61 \pm 0.30\end{array}$ & $\begin{array}{c}57 \cdot 2 \pm 15 \cdot 0 \\
33.7 \pm 10.1 \\
9.2 \pm 9.5 \\
1.52 \pm 0.23\end{array}$ & $\begin{array}{l}44.8 \pm 8.9 \\
41.0 \pm 1.5 \\
14.1 \pm 7.5 \\
1.69 \pm 0.16\end{array}$ \\
\hline iii Chronic hypoxia & 11 & $\begin{array}{c}\text { Grade } 1 \% \\
\text { Grade } 2 \% \\
\text { Grade } 3 \% \\
\text { Overall index }\end{array}$ & $\begin{array}{c}48 \cdot 7 \pm 16 \cdot 3 \\
42.5 \pm 12 \cdot 1 \\
9.6 \pm 5 \cdot 0 \\
1.60 \pm 0.21\end{array}$ & & $\begin{array}{c}50.2 \pm 13.6 \\
41.0 \pm 11.3 \\
8.8 \pm 3.5 \\
1.59 \pm 0.16\end{array}$ \\
\hline
\end{tabular}

$12 \% \mathrm{O}_{2}$, and air respectively, while the degranulation index for the whole lung was $1.61,1.52$, and 1.69 respectively (not significant).

The degree of degranulation was similar in experiment $i$ where ethyl chloride and pentobarbitone were used and in experiment ii where ether and pentobarbitone were used. Also, there was no difference in degranulation between experiment $i$, where the lung was fixed during acute hypoxia, and experiment ii, where there was an interval before fixation. There was no evidence of increased degranulation during either acute or chronic hypoxia.

In the 48/80 experiment the overall degranulation index for the two rats was 2.09 and the grading was $1=22 \cdot 2 \%, 2=47.0 \%$, and $3=30.8 \%$. These results suggest that the technique was sufficiently sensitive to detect mast cell degranulation.

\section{DISCUSSION}

POPULATION AND DISTRIBUTION OF MAST CELLS Chronic exposure to hypoxia was characterized by an increase in the numbers of lung mast cells, especially around the alveoli and small vessels (Fig. 2). It is in these situations that the mast cells are exposed to alveolar gases and it is the small peripheral vessels that hypertrophy in chronic hypoxia (Hunter et al., 1974; Barer and Mungall, 1974). In experiment e, there was a significant linear relationship between the alveolar and small vessel mast cell count and RV weight (Fig. 1). The hypothesis that mast cell hyperplasia leads to pulmonary hypertension and consequent RV hypertrophy seems particularly attractive in this context. Since completing this study, Kay et al. (1974) have demonstrated mast cell hyperplasia in the lungs of rats kept in a hypobaric chamber (equivalent to $10 \% \mathrm{O}_{2}$ ) for 21 days. They correlated $\log \mathrm{RV}$ weight with $\log$ mast cell count for both their experimental and control animals.

In one of the 21-day experiments (d) and in the 14-day experiment $(\mathrm{g})$ there was no increase in mast 7 cell count. It is likely that 21 days is approximately the threshold for mast cell hyperplasia. However, it is known that only 14 days' exposure to $10 \% \mathrm{O}_{2}$ is necessary to produce RV hypertrophy (Hunter et al., $\overrightarrow{0}$ 1974). This anomaly is difficult to reconcile with a oे functional role for mast cells in hypoxic pulmonary vascular disease. Possibly mast cell hyperactivity precedes hyperplasia.

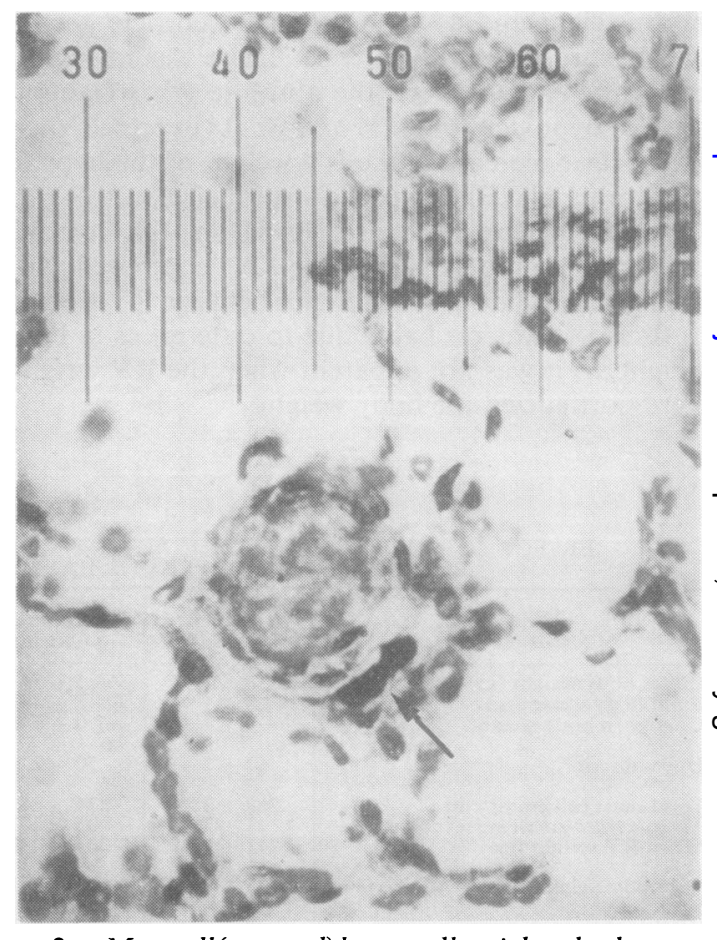

FIG. 2. Mast cell(arrowed) by a small peripheral pulmonary vessel. Experiment a, Table I. Vessel diameter $=32.5 \mu \mathrm{m}$ (each graticule division $=2.5 \mu \mathrm{m})$. Azure eosin $\times 400$. 
Mast cells have other functions beside the storage and release of vasoactive amines. They are associated with the laying down of connective tissue and oedema formation (Riley, 1959). It is possible that in chronic hypoxia the mast cells are related to these functions rather than to vasoconstriction. However, there was no microscopic evidence of pulmonary oedema in the hypoxic animals.

Lung mast cell hyperplasia has previously been reported in association with the pulmonary hypertension of mitral stenosis (Heath, Trueman, and Sukonthamarn, 1969) and Crotalaria poisoning (Takeova, Angevine, and Lalich, 1962; Kay, Gillund, and Heath, 1967). In these studies, the mast cell hyperplasia correlated better with chronic exudation of fluid and the formation of new fibrous tissue than with RVH.

DISODIUM CROMOGLYCATE EXPERIMENTS The failure of disodium cromoglycate to prevent RVH infers that mast cells do not have a functional role in the development of RVH in chronic hypoxia. However, other possibilities should be considered. Although there is good circumstantial evidence that disodium cromoglycate stabilizes the mast cell regardless of the stimulus, there is no definite proof that it is effective in hypoxic degranulation. Also the acute hypoxic experiments have failed to confirm Haas and Bergofsky's original observation that hypoxia does indeed cause mast cell degranulation (Haas and Bergofsky, 1972). Kay and Grover (1975) showed that disodium cromoglycate inhibited the pulmonary pressor response to acute hypoxia in three out of eight anaesthetized dogs, though Howard et al. (1975) were unable to confirm this.

Inadequate dosage of disodium cromoglycate is a possible explanation. However, the dose used is known to stabilize the mast cell in sensitivity reactions, and the intraperitoneal route of administration should have ensured effective levels for the duration of each hypoxic exposure. A further anomaly is the demonstration of $\mathrm{RVH}$ in both hypoxic groups (A and B) without an increase in mast cell numbers. Possibly four hours' hypoxia daily was insufficient stimulus for mast cell hyperplasia, or possibly, as with the continuous exposure experiments, RVH predates mast cell hyperplasia.

The depressant action of disodium cromoglycate on body weight has not previously been reported and is unexplained. From Table II it can be seen that the low body weights in group A actually made the normalized RV weights significantly heavier than in group B.

DEGRANULATION EXPERIMENTS There was no significant difference between the degree of degranula- tion, either between the hypoxic and control animals or between the three experiments. The reason for the discrepancy between these results and Haas and Bergofsky's (1972) demonstration of hypoxic mast cell degranulation is not clear. Haas and Bergofsky only measured degranulation in perivascular mast cells though this is unlikely to be the explanation as in experiment ii (Table III) the degree of degranulation in the perivascular mast cells and in the lung as a whole was similar. The demonstration of mast cell degranulation in over one-third of the control animals is in agreement with Haas and Bergofsky's observations. The reason for this degranulation has not been resolved; possibly the trauma of dissection and tissue processing is responsible.

I wish to thank Professor J. Richmond for allowing me the facilities of his department, Dr. G. R. Barer and Dr. P. Howard for their constant encouragement, help, and criticism, Mr. Graham Tate and Miss Enid Frith for invaluable technical assistance, Fisons Pharmaceuticals Limited for the supply of Intal, and the Sheffield AHA Special Trustees, who generously supported this project. Professor W. Bartley very kindly lent one of the hypoxic chambers.

\section{REFERENCES}

Abraham, A. S., Cumming, G., Horsfield, K., and Prowse, K. (1970). Regional hypoxia and distribution of blood flow. Scandinavian Journal of Respiratory Diseases, 51, 33.

, Kay, J. M., Cole, R. B., and Pincock, A. C. (1971). Haemodynamic and pathological study of the effect of chronic hypoxia and subsequent recovery of the heart and pulmonary vasculature of the rat. Cardiovascular Research, 5, 95.

Altounyan, R. E. C. (1967). Inhibition of experimental asthma with a new compound-disodium cromoglycate, 'Intal'. Acta Allergolica, 22, 487.

—, Cox, J. S. G., and Orr, T. S. C. (1970). Biological and pharmacological basis of disodium cromoglycate therapy. In: Excerpta Medica International Congress Series, No. 232. New Concepts in Allergy and Clinical Immunology, pp 377-384. Proceedings of the VII International Congress of Allergology, Florence.

Assem, E. S. K. and Richter, A. W. (1971). Comparison of in vivo and in vitro inhibition of the anaphylactic mechanism by $\beta$ adrenergic stimulants and disodium cromoglycate. Immunology, 21, 729.

Aviado, D. M., Samanek, M., and Folle, L. E. (1966). Cardiopulmonary effects of tobacco and related substances. I. Release of histamine during inhalation of cigarette smoke and anoxemia in the heart-lung and intact dog preparation. Archives of Environmental Health, 12, 705 .

Barer, G. R., Howard, P., McCurrie, J. R., and Shaw, J. W. (1969). Changes in the pulmonary circulation after bronchial occlusion in anaesthetised dogs and cats. Circulation Research, 25, 747. 
and McCurrie, J. R. (1969). Pulmonary vasomotor responses in the cat; the effects and inter-relationships of drugs, hypoxia and hypercapnia. Quarterly Journal of Experimental Physiology, 54, 156.

_ and Mungall, I. (1974). Hyperplasia of mast cells in chronically hypoxic lungs. Journal of Physiology, 241, 31P.

Brashear, R. E., Martin, R. R., and Ross, J. C. (1970). In vivo histamine levels with hypoxia and compound 48/80. American Journal of Medical Science, 260, 21.

Bray, R. E. and van Arsdel Jr, P. P. (1961). In vitro histamine release from rat mast cells by chemical and physical agents. Proceedings of The Society of Experimental Biology and Medicine, 105, 255.

Clarke, P. S. (1971). Effect of disodium cromoglycate on exacerbations of asthma produced by hyperventilation. British Medical Journal, 1, 317.

Cox, J. S. G. (1967). Disodium cromoglycate (FPL 670) (Intal): A specific inhibitor of reaginic antibody/ antigen mechanisms. Nature, 216, 1328.

Cryer, A., and Bartley, W. (1974). The design and use of a hypoxic chamber for small animals. Laboratory Practice, 23, 713.

Davies, S. E. (1968). Effect of disodium cromoglycate on exercise induced asthma. British Medical Journal, 3, 593.

Dawson, C. A., Delano, F. A., Hamilton, L. H., and Stekiel, W. J. (1974). Histamine releasers and hypoxic vasoconstriction in isolated cat lungs. Journal of Applied Physiology, 37, 670.

de Kock, M. A. (1970). Mechanisms of bronchial obstruction in man. In: Bronchitis 111. Proceedings of the Third International Symposium on Bronchitis, edited by N. G. M. Orie and R. van der Lende, pp. 300-311 and p. 354. Royal Vangorcum, Assen, The Netherlands, and Thomas, Springfield, Illinois.

Euler, U. S. von and Liljestrand, G. (1946). Observations on the pulmonary arterial blood pressure in the cat Acta Physiologica Scandinavica, 14, 301.

Fawcett, D. W. (1954). Cytological and pharmacological observations on the release of histamine by mast cells. Journal of Experimental Medicine, 100, 217.

Haas, F. and Bergofsky, E. H. (1972). Role of the mast cell in the pulmonary pressor response to hypoxia. Journal of Clinical Investigation, 51, 3154.

Hasleton, P. S., Heath, D. and Brewer, D. B. (1968). Hypertensive pulmonary vascular disease in states of chronic hypoxia. Journal of Pathology and Bacteriology, 95, 431.

Hauge, A. (1968). Role of histamine in hypoxic pulmonary hypertension in the rat. Circulation Research, 22, 371.

- and Staub, N. C. (1969). Prevention of hypoxic vasoconstriction in cat lung by histamine-releasing agent 48/80. Journal of Applied Physiology, 26, 693.

Heath, D., Brewer, D., and Hicken, P. (1968). Cor Pulmonale in Emphysema, p. 91 and p. 104. Thomas, Springfield, Illinois.

- Trueman, T., and Sukonthamarn, P. (1969) Pulmonary mast cells in mitral stenosis. Cardiovascular Research, 3, 467.

Hicken, P., Heath, D., Brewer, D. B., and Whitaker, W. (1965). The small pulmonary arteries in emphysema. Journal of Pathology and Bacteriology, 90, 107.
Howard, P., Barer, G. R., Thompson, B., Warren, P. M., Abbott, C. J., and Mungall, I. P. F. (1975). Factors causing and reversing vasoconstriction in unventilated lung. Respiration Physiology. (In press).

Hunter, C., Barer, G. R., Shaw, J., and Clegg, E. J. (1974). Growth of the heart and lungs in hypoxic rodents; a model of human hypoxic disease. Clinical Science and Molecular Medicine, 46, 375.

Kay, J. M., Gillund, T. D., and Heath, D. (1967). Mast cells in the lungs of rats fed on Crotalaria spectabilis seeds. American Journal of Pathology, 51, 1031.

_, Waymire, J. C., and Grover, R. F. (1974). Lung mast cell hyperplasia and pulmonary histamine-forming capacity in hypoxic rats. American Journal of Physiology, 226, 178.

- and Grover, R. F. (1975). Lung mast cells and hypoxic pulmonary hypertension. In: Progress in Respirction Research. Pulmonary Circulation. Karger, Basel. (In press).

Kerr, J. W., Govindaraj, M., and Patel, K. R. (1970). Effect of alpha receptor blocking drugs and disodium cromoglycate on histamine hypersensitivity in bronchial asthma. British Medical Journal, 2, 139.

Marshall, R. (1972). Protective effect of disodium cromoglycate on rat peritoneal mast cells. Thorax, 27, 38.

McGrath, J. J., Prochazka, J., Pelouch, V., and Ostadal, B. (1973). Physiological responses of rats to intermittent high altitude stress: effects of age. Journal of Applied Physiology, 34, 289.

Mungall, I. P. F. and Barer, G. R. (1975). Lung vessels and mast cells in chronically hypoxic rats. In: Progress in Respiration Research. Pulmonary Circulation. Karger, Basel (In press).

Naeye, R. L. and Bickerman, H. A. (1959). The effects of hypoxaemia on the pulmonary arterial bed of humans and rats. Federation Proceedings, 18, 497.

Orr, T. S. C. and Cox, J. S. G. (1969). Disodium cromoglycate, an inhibitor of mast cell degranulation and histamine release by phospholipase A. Nature, 223, 197.

Pepys, J., Hargreaves, F. E., Chan, M., and McCarthy, D. S. (1968). Inhibitory effects of disodium cromoglycate on allergy inhalation tests. Lancet, 2, 134.

Riley, J. F. (1959). The Mast Cells, pp. 22, 58, 140-1, and 163. Livingstone, Edinburgh. and West, G. B. (1953). The presence of histamine in tissue mast cells. Journal of Physiology, 120, 528. and West, G. B. (1955). Tissue mast cells. Studies with $N$ a histamine-liberator of low toxicity (compound $\mathrm{N}$ 48/80). Journal of Pathology and Bacteriology, 69, 269.

Takeova, O., Angevine, D. M., and Lalich, J. J. (1962). ర్ Stimulation of mast cells in rats fed various chemicals. American Journal of Pathology, 40, 545.

Widimsky, J., Urbanova, D., Ressl, J., Ostadal, B., 央 Pelouch, V., and Prochazka, J. (1972). The effect of 7 intermittent hypoxia on the myocardium in the rat. Bulletin de Physio-pathologie Respiratoire, 8, 1400.

Requests for reprints to: Dr. I. P. F. Mungall, Section of Experimental Medicine, University of Sheffield $\underset{<}{\sigma}$ Medical School, Beech Hill Road, Sheffield S10 2RX. 